\title{
PENGGUNAAN TEPUNG Azolla microphilla DAN ENZIM SELULASE DALAM RANSUM TERHADAP PENAMPILAN PRODUKSI DAN NILAI EKONOMIS ITIK LOKAL KERINCI JANTAN
}

\author{
Noferdiman ${ }^{1)}$, Lisna') dan Yusma Damayanti ${ }^{2)}$ \\ 1)Program Studi Peternakan Fakultas Peternakan Universitas Jambi \\ 2)Program Studi Agribisnis Fakultas Pertanian Universitas Jambi \\ email: noferdiman@unja.ac.id
}

\begin{abstract}
ABSTRAK
Penelitian ini bertujuan untuk mengetahui tingkat pengunaan tepung Azolla dan enzim selulase dalam ransum untuk mendapatkan penampilan produksi dan nilai ekonomis itik lokal Kerinci jantan yang terbaik. Itik lokal Kerinci umur 1 hari sebanyak 144 ekor, secara acak dibagi ke dalam 6 kombinasi perlakuan dengan mengunakan rancangan acak lengkap pola faktorial $3 \times 2$ dengan 3 kali ulangan, masing-masing terdiri dari 8 ekor. Perlakuan terdiri dari 3 tingkat penggunaan tepung azolla yaitu: 0,10 , dan $20 \%$ dan 2 perlakuan penambahan enzim selulase, yaitu: o,oo dan 0,10 \%. Hasil penelitian menunjukkan bahwa tingkat penggunaan tepung azolla dan enzim selulase serta interaksinya memberi pengaruh yang tidak nyata $(\mathrm{P}>0.05)$ terhadap konsumsi ransum, pertambahan bobot badan, dan bobot karkas. Penggunaan tepung azolla dan enzim selulase memberi pengaruh yang sangat nyata $(\mathrm{P}<0,01)$ terhadap konversi ransum dan nilai ekonomis IOFC, namun tidak terdapat interaksi antara kedua perlakuan tersebut. Penambahan enzim selulase 0,10 \% dalam ransum yang mengandung tepung azolla dapat meningkatkan penampilan itik lokal Kerinci jantan. Kesimpulan hasil penelitian ini adalah penambahan 0,10 \% enzim selulase dalam ransum yang mengandung tepung azolla $20 \%$ memberi penampilan itik lokal Kerinci yang terbaik.
\end{abstract}

Kata kunci: enzim selulase, itik lokal Kerinci jantan, tepung Azolla microphilla

\section{PENDAHULUAN}

Pakan merupakan salah satu faktor penentu untuk keberhasilan suatu usaha peternakan unggas. Ketersediaan bahan-bahan pakan ternak yang lazim dipakai akhir-akhir ini semakin terasa sulit. Keadaan ini antara lain disebabkan oleh meningkatnya harga bahan-bahan pakan ternak, terutama bahan baku impor seperti jagung, bungkil kedelai, dan tepung ikan. Pada tahun 2010 Indonesia masih mengimpor bungkil kedele sebanyak 2.450.00o ton/tahun, jagung 450.00o ton/tahun, dan tepung ikan 176.500 ton/ tahun (BPS, 2011). Di sisi lain harga pakan akan mempengaruhi efisiensi usaha dan mengingat biaya pakan ternak mencapai $60-70 \%$ dari seluruh biaya proses produksi peternakan (Sudrajat, 2000).

Penggunaan bahan-bahan pakan impor dapat diturunkan atau dikurangi melalui penggunaan sumberdaya lokal, antara lain dengan menggali potensi bahan pakan non konvensional. Salah satunya adalah Azolla microphylla. Tanaman A. microphylla (Azolla) mempunyai potensi yang cukup besar sebagai bahan pakan sumber protein untuk ternak unggas. Pertumbuhan yang relatif cepat pada Azolla, dimana dalam waktu 2 minggu dapat diperoleh biomassa 20 ton segar/ha yang berasal dari bibit 0,5 ton/ha dan mengandung protein kasar cukup tinggi yaitu: 31,25 \% (Quebral, 1998). Penelitian Supartoto et al., (2012) melaporkan bahwa pertumbuhannya relatif cepat yakni membutuhkan waktu mengganda dua sampai sembilan hari.

Di samping pertumbuhan yang relatif cepat, Azolla mengandung xanthophyl: $256 \mathrm{mg} / \mathrm{kg}$ dan BETN: 35 - 39 \% (Querubin et al., 1986; Djojosuwito, 2000). Penelitian Noferdiman dan Zubaidah (2012) A. microphylla mengandung protein kasar 26,08 \%, lemak 2,20 \%, serat kasar 19,52 \%, Abu 13,94\% dan BETN 40,06 \%. Sedangkan Kusumanto (2008) melaporkan bahwa kandungan nutrien $A$. microphylla yaitu protein $31,25 \%$, lemak $7,5 \%$, gula terlarut $3,5 \%$ dan serat kasar $13 \%$. Chatterjee et.al. (2013) melaporkan hasil analisis kimia $A$. microphylla yaitu: bahan organik 80,53\%, protein kasar 24,06\%, serat kasar 13,44\%, lemak kasar 3,27\%, abu 19,47\%, BETN $37,71 \%$.

Tanaman A. microphylla diharapkan dapat menunjang bahkan menggantikan bahan pakan sumber protein impor dan mahal harganya seperti; bungkil kedele. Serat kasar merupakan suatu kendala untuk dimanfaatkan sebagai bahan pakan ternak unggas, dikarenakan unggas memiliki sistem pencernaan tunggal tidak menghasilkan enzim selulase untuk mencerna komponen serat kasar. 
Penelitian Noferdiman (1999) melaporkan bahwa penggunaan Azolla tanpa pengolahan dalam ransum itik Mojosari jantan hanya dapat digunakan $5 \%$ dan tidak menggangu penampilan produksi.

Pemanfaatan Azolla belum dapat bisa digunakan secara optimal pada ransum ternak unggas, termasuk itik karena mengandung serat kasar yang cukup tinggi. Hal ini dikarenakan itik tidak bisa menghasilkan enzim selulase, maka diperlukan upaya agar Azolla dapat termanfaatkan secara optimal dengan menambahkan enzim selulase di dalam ransum maupun langsung ke saluran pencernaannya. Penelitian terdahulu sering dilakukan dengan cara fermentasi terlebih dahulu, tetapi proses fermentasi memerlukan sarana, cara dan waktu yang lebih lama, sehingga kurang efisien dalam penerapannya.

Salah satunya cara efisien dan efektif adalah penambahan enzim selulase komersial secara langsung dalam ransum. Enzim selulase adalah enzim terinduksi yang disintesis mikroorganisme selama ditumbuhkan dalam medium selulosa (Lee dan Koo, 2001). Suplementasi enzim selulase bertujuan untuk mendegradasi molekul komplek seperti selulosa menjadi karbohidrat yang lebih sederhana seperti glukosa. Enzim yang digunakan pada penelitian ini adalah enzim spesifik yang di dalamnya khusus enzim selulase.

Saat ini sudah mulai dilakukan penelitian tentang penggunaan enzim dalam ransum yang dapat bermanfaat dalam penyerapan nutrien dalam saluran pencernaan ayam maupun itik (Leeson dan Summers, 2005) dan banyak produk enzim komersial tersedia dalam industri perunggasan. Seperti halnya sifat fraksi serat kasar secara umum yang dapat menghalangi kerja enzim pencernaan terhahap digesta (Chin, 2002). Walaupun demikian degradasi selulosa dengan menggunakan enzim selulase dapat menghasilkan manosakarida dan glukosa yang dapat berfungsi sebagai komponen pakan fungsional.

Dewasa ini banyak upaya yang telah dilakukan peneliti untuk meningkatkan kecernaan zat gizi bahan pakan berserat, di antaranya adalah suplementasi enzim (Meng et al., 2005), di samping formulasi ransum yang mengandung cukup protein kasar, asam amino esensial, dan energi ransum, serta suplementasi ransum yang dapat menghasilkan manno-oligosakarida yang dapat berfungsi sebagai prebiotik dan feed aditif dan penambahan selulase dalam ransum yang mengandung pakan berserat dilaporkan dapat meningkatkan kecernaan bahan kering, energi metabolis (Kensch, 2008). Menurut Jaelani (2011) peningkatan kecernaan ini sama efektifnya dengan penambahan enzim (multi) komersil pada dosis $2 \mathrm{~g} / \mathrm{kg}$ bungkil inti sawit. Penelitian penambahan enzim dalam ransum yang mengandung Azolla belum banyak dilaporkan dan relatif terbatas pada enzim pendegradasi serat yang umum ( $\beta$-glukanase, silanase, pektinase, selulosa dan kombinasi enzim-enzim pendegradasi serat tersebut). Oleh karena itu, penelitian ini telah dilakukan untuk mengevaluasi pengaruh penggunaan Azolla dengan suplementsi enzim selulase terhadap pertumbuhan itik lokal Kerinci.

\section{METODE PENELITIAN}

Penelitian ini menggunakan itik lokal Kerinci jantan berumur satu hari sebanyak 144 ekor. Kandang percobaan yang digunakan adalah kandang baterai berjumlah 18 unit dengan ukuran 120 x 100 x $60 \mathrm{~cm}$ yang terbuat dari kawat. Kandang dilengkapi dengan lampu 60 watt, ditempatkan dibagian tengah yang berfungsi sebagai alat pemanas dan penerang.

Bahan Azolla microphylla diperoleh dari kolam ikan milik Dinas Perikanan Provinsi Jambi dan pembiakan sendiri di kolam ikan Kelompok Tani Desa Tanjung Harapan Kerinci, sedangkan enzim selulase yang digunakan adalah enzim cellulase merk microcrystalin berwarna putih berbentuk tepung. Bahan-bahan penyusun ransum lainnya adalah jagung kuning, dedak halus, dan konsentrat diperoleh dari Poultry Shop Simpang Sungai Duren Jambi. Susunan ransum perlakuan itik lokal Kerinci dapat dilihat pada Tabel 1.

Tabel 1. Susunan Ransum, Kandungan Gizi dan Energi Metabolis Ransum-Perlakuan (0 - 7 minggu).

\begin{tabular}{lrcr}
\hline \multirow{2}{*}{ Bahan Pakan } & \multicolumn{3}{c}{ Ransum Perlakuan } \\
\cline { 2 - 4 } & \multicolumn{1}{c}{ A-0 } & A-10 & \multicolumn{1}{c}{ A-20 } \\
\hline Jagung Giling & 38,00 & 39,00 & 39,00 \\
Dedak Halus & 9,00 & 7,00 & 8,00 \\
Konsentrat & 53,00 & 44,00 & 33,00 \\
Azolla & 0,00 & 10,00 & 20,00 \\
\hline \multicolumn{1}{c}{ Total } & 100,00 & 100,00 & 100,00 \\
\hline
\end{tabular}

Tabel 2. Kandungan Gizi dan Energi Metabolis Hasil Perhitungan

\begin{tabular}{lrrr}
\hline Protein Kasar (\%) & 20,25 & 20,36 & 20,12 \\
Serat Kasar (\%) & 5,56 & 6,03 & 6,74 \\
Lemak (\%) & 4,32 & 3,95 & 3,53 \\
Ca (\%) & 1,26 & 1,15 & 1,00 \\
P (\%) & 0,64 & 0,60 & 0,55 \\
ME (kkal/kg) & 2795,24 & 2810,52 & 2789,64 \\
\hline
\end{tabular}

Rancangan yang digunakan adalah Rancangan Acak Lengkap (RAL) Pola Faktorial, dengan perlakuan terdiri atas 3 tingkat penggunaan tepung azolla dalam ransum yaitu: (A-0) o \%, (A-10) $10 \%$, dan (A-20) $20 \%$ dan 2 perlakuan penambahan enzim selulase dalam ransum yaitu : (E-O,Oo) o,oo \% dan (E-0,10) $10 \%$ dengan ulangan 3 kali, setiap ulangan terdiri 
atas 8 ekor itik lokal Kerinci. Analisis sidik ragam dilakukan dari data yang terkumpul dan jka berbeda dilanjutkan dengan uji jarak berganda Duncan (Steel dan Torrie, 1989).

Peubah yang diukur adalah konsumsi pakan (g/ ekor), pertambahan bobot badan (g/ekor), konversi pakan, bobot karkas (g/ekor), karkas (\%), dan nilai income over feed and chick cost (IOFCC).

\section{HASIL DAN PEMBAHASAN}

\section{Konsumsi Ransum, Pertambahan Bobot Badan, dan Konversi Ransum}

Hasil analisis ragam menunjukkan bahwa perlakuan tingkat penggunaan Azolla dalam ransum memberi pengaruh yang sangat nyata $(\mathrm{P}<0,01)$ terhadap konsumsi ransum, begitu juga untuk penambahan enzim selulase dalam ransum memberi pengaruh yang sangat nyata $(\mathrm{P}<\mathrm{O}, \mathrm{O} 1)$. Interaksi antara penggunaan Azolla dan enzim selulase dalam ransum memberi pengaruh yang tidak nyata $(\mathrm{P}>0,05)$. Uji jarak Duncan menunjukkan bahwa berbeda nyata $(\mathrm{P}<0,05)$ antara perlakuan penggunaan Azolla dalam ransum terhadap konsumsi ransum, dimana rataan konsumsi ransum cenderung menurun pada masing-masing perlakuan penggunaan Azolla dalam ransum (A-0, A-10, dan A-20). Begitu juga penambahan enzim dalam ransum berbeda nyata $(\mathrm{P}<0,05)$ terhadap konsumsi ransum. Rataan enzim selulase $(\mathrm{E}-\mathrm{O}, 10)$ dalam ransum memberi konsumsi lebih tinggi dibanding tanpa penambahan enzim (E-o,oo). Rataan konsumsi ransum (g/ekor), pertambahan bobot badan (g/ekor), dan konversi ransum dapat dilihat pada Tabel 2.

Penggunaan Azolla dalam ransum dapat mengakibatkan naiknya kandungan serat kasar dalam ransum meskipun masih dalam batas toleransi serat kasar (perlakuan A-20) pada unggas, tetapi cenderung meningkat. Penelitian yang dilakukan oleh Hatta (2005) menjelaskan bahwa semakin tinggi kandungan serat pada ransum maka semakin rendah pula konsumsi ransum. Serat kasar yang terkandung dalam ransum bersifat bulky yang menyebabkan kapasitas tembolok ayam yang terbatas akan cepat penuh dan konsumsi akan terhenti. Selanjutnya dijelaskan oleh Amrullah (2003), menyatakan bahwa serat kasar yang tinggi menyebabkan unggas merasa kenyang, sehingga dapat menurunkan konsumsi, karena serat kasar bersifat mengenyangkan. Jika ayam merasa kenyang, maka akan berhenti mengkonsumsi ransum, karena pada unggas kebutuhan pertama konsumsi adalah memenuhi kebutuhan energinya. Penambahan enzim selulase $(\mathrm{E}-0,10)$ dalam ransum mengakibatkan meningkatnya konsumsi ransum. Hal ini disebabkan oleh kerja enzim yang mampu merombak bahan pakan yang sulit dicerna oleh unggas menjadi lebih sederhana, dimana selulosa mampu meningkatkan kualitas ransum dengan mendegradasi komponen serat kasar terutama selulosa menjadi yang lebih sederhana.

Tabel 3. Rataan Konsumsi Ransum (g/ekor), Pertambahan Bobot Badan (g/ekor), dan Konversi Ransum.

\begin{tabular}{|c|c|c|c|c|c|}
\hline \multirow{2}{*}{ Peubah } & \multirow{2}{*}{ Enzim (\%) } & \multicolumn{3}{|c|}{ Tingkat Penggunaan Azolla (\%) } & \multirow{2}{*}{ Rataan } \\
\hline & & A-0 & A-10 & $A-20$ & \\
\hline \multirow{3}{*}{$\begin{array}{l}\text { Konsumsi Ransum } \\
\text { (g/ekor) }\end{array}$} & $E-0,00$ & 4216,75 & 4076,14 & 4088,92 & $4088,32^{b}$ \\
\hline & E-0,10 & 4413,86 & 4311,00 & 4182,58 & $4302,48^{a}$ \\
\hline & Rataan & $4315,30^{a}$ & $4193,57^{b}$ & $4078,22^{c}$ & \\
\hline \multirow{3}{*}{$\begin{array}{l}\text { Pertambahan } \\
\text { Bobot Badan (g/ } \\
\text { ekor) }\end{array}$} & $E-0,00$ & 1067,14 & 975,59 & 982,52 & $1008,42^{b}$ \\
\hline & $E-0,10$ & 1197,89 & 1147,90 & 1110,23 & $1152,01^{a}$ \\
\hline & Rataan & $1132,52^{a}$ & $1061,75^{\mathrm{ab}}$ & $1046,39^{b}$ & \\
\hline \multirow[t]{3}{*}{ Konversi Ransum } & $E-0,00$ & 3,96 & 4,18 & 4,06 & $4,06^{a}$ \\
\hline & $E-0,10$ & 3,70 & 3,76 & 3,77 & $3,74^{b}$ \\
\hline & Rataan & 3,83 & 3,97 & 3,92 & \\
\hline
\end{tabular}

Keterangan : Huruf kecil yang berbeda pada baris dan kolom yang sama menunjukkan pengaruh berbeda nyata $(P<0,05)$.

Hasil analisis ragam menunjukkan bahwa perlakuan tingkat penggunaan Azolla dalam ransum memberi pengaruh yang nyata $(\mathrm{P}<0,05)$ terhadap pertambahan bobot badan, begitu juga untuk penambahan enzim selulase dalam ransum memberi pengaruh yang sangat nyata $(\mathrm{P}<0,01)$. Interaksi antara penggunaan Azolla dan enzim selulase dalam ransum memberi pengaruh yang tidak nyata $(\mathrm{P}>0,05)$. Uji jarak Duncan menunjukkan bahwa berbeda nyata $(\mathrm{P}<0,05)$ antara perlakuan penggunaan Azolla dalam ransum terhadap pertambahan bobot badan. Rataan petambahan bobot badan antara penggunaan Azolla A-o dengan A-10 tidak berbeda nyata $(\mathrm{P}>0,05)$ tetapi berbeda nyata $(\mathrm{P}<0,05)$ dengan $\mathrm{A}-2 \mathrm{O}$, begitu juga untuk perlakuan A-10 dengan A-20 tidak berbeda nyata $(\mathrm{P}>0,05)$. Penambahan enzim dalam ransum berbeda nyata $(\mathrm{P}<0,05)$ terhadap pertambahan bobot badan, penggunaan Enzim (E-10) lebih baik dibanding tanpa enzim (E-oo).

Pertambahan bobot badan itik juga dapat dipengaruhi oleh banyak sedikitnya itik mengkonsumsi ransum. Semakin banyak itik mengkonsumsi ransum, maka semakin tinggi pula pertambahan bobot badannya, dan semakin sedikit itik mengkonsumsi ransum maka semakin rendah pula pertambahan bobot badan itiknya. Pada Tabel 2 terlihat bahwa konsumsi ransum cenderung menurun dengan meningkatnya penggunaan Azolla dalam ransum. Konsumsi ransum yang mengandung Azolla ini diakibatkan efek serat yang juga cenderung meningkat pada masing-masing perlakuan. Serat kasar akan berdampak pada konsumsi yang cenderung menurun. Hal ini disebabkan terbatasnya tembolok menampung makanan karena kerapatan jenis yang rendah. Menurut Wahyu (2004), pakan yang mengandung serat kasar 
tinggi berakibat tembolok tidak dapat mencapai volume yang lebih besar sehingga konsumsi pakan menjadi terbatas. Jika konsumsi menjadi terbatas maka daya serap zat-zat makanan melalui saluran pencernaan juga berkurang, hal ini akan berdampak pada pertambahan bobot badan itik.

Penambahan enzim selulase $(E-0,10)$ dalam ransum mengakibatkan meningkatnya pertambahan bobot badan itik jika dibandingkan dengan tanpa enzim (E-o,oo). Hal ini disebabkan oleh kerja enzim yang mampu merombak bahan pakan yang sulit dicerna oleh unggas menjadi lebih sederhana, dimana selulosa mampu meningkatkan kualitas ransum dengan mendegradasi komponen serat kasar terutama selulosa menjadi yang lebih sederhana. Penambahan enzim yang awalnya diharapkan dapat berpengaruh secara tidak langsung pada pertumbuhan, dalam penelitian ini tampak terlihat. Hal ini kemungkinan dikarenakan kompleksitas serat kasar, terutama komponen selulase. Penambahan enzim selulase diduga dapat bekerja secara spesifik untuk mendegradasi fraksi serat ransum secara utuh untuk menimbulkan pengaruh nyata. Hasil penelitian Sundu et al., (2004) menunjukkan efektifitas penambahan enzim (selulose, glukanase, xylanase, dan fitase) dalam ransum yang mengandung komponen serat lebih terlihat pada kecernaan protein, lemak, abu, dan energi metabolis ransum.

Hasil analisis ragam menunjukkan bahwa perlakuan tingkat penggunaan Azolla dalam ransum memberi pengaruh yang tidak nyata $(\mathrm{P}>0,05)$ terhadap konversi ransum, tetapi untuk penambahan enzim selulase dalam ransum memberi pengaruh yang sangat nyata $(\mathrm{P}<\mathrm{O}, \mathrm{O} 1)$. Interaksi antara penggunaan Azolla dan enzim selulase dalam ransum memberi pengaruh yang tidak nyata $(\mathrm{P}>0,05)$. Uji jarak Duncan menunjukkan bahwa penambahan enzim dalam ransum berbeda nyata $(\mathrm{P}<0,05)$ terhadap konversi ransum, penggunaan Enzim (E-10) lebih baik dibandingkan tanpa enzim (E-Oo).

Angka konversi ransum menunjukkan suatu prestasi penggunaan ransum oleh seekor ternak itik. Semakin tinggi nilai konversi ransum menunjukkan semakin banyak ransum yang dibutuhkan untuk meningkatkan bobot badan per satuan berat. Demikian juga sebaliknya semakin rendah nilai konversi ransum semakin efisien penggunaan ransum tersebut oleh ternak ayam. Konversi ransum dalam percobaan ini berkisar antara 3,74-4,06, lebih tinggi sedikit dibanding dengan penelitian yang dilakukan oleh Manin (2003) yaitu 3,26 - 3,57 pada itik lokal Kerinci umur 8 minggu.

Konversi ransum yang menggunakan Azolla hingga $20 \%$ (A-20) dalam ransum menghasilkan angka konversi yang tidak berbeda dengan A-o dan A-10, kecuali dengan penambahan enzim $0,10 \%$ dalam ransum memberi konversi ransum yang terbaik. Hal ini disebabkan perlakuan A-20 menunjukkan penurunan bobot badan yang sejalan dengan penurunan pada konsumsi ransumnya, sehingga diperoleh konversi ransum sebanding dengan perlakuan lainnya, karena konversi ransum merupakan perbandingan antara konsumsi ransum dengan pertambahan bobot badan. Penelitian Noferdiman dan Zubaidah (2012) melaporkan bahwa penggunaan Azolla fermentasi dapat digunakan hingga $15 \%$ dalam ransum itik lokal Kerinci dan menghasilkan konversi ransum yang sama dengan ransum kontrol.

\section{Bobot Karkas Mutlak dan Karkas Relatif}

Hasil analisis ragam menunjukkan bahwa perlakuan tingkat penggunaan Azolla dalam ransum memberi pengaruh yang sangat nyata $(\mathrm{P}<0,01)$ terhadap bobot karkas, begitu juga untuk penambahan enzim selulase dalam ransum memberi pengaruh yang sangat nyata $(\mathrm{P}<0,01)$. Interaksi antara penggunaan Azolla dan enzim selulase dalam ransum memberi pengaruh yang tidak nyata $(\mathrm{P}>0,05)$. Uji jarak Duncan menunjukkan bahwa berbeda nyata $(\mathrm{P}<0,05)$ antara perlakuan penggunaan Azolla dalam ransum terhadap bobot karkas. Rataan karkas antara penggunaan Azolla A-o dengan A-10 tidak berbeda nyata $(\mathrm{P}>0,05)$ tetapi berbeda nyata $(\mathrm{P}<0,05)$. Penambahan enzim dalam ransum berbeda nyata $(\mathrm{P}<0,05)$ terhadap bobot karkas mutlak, penggunaan Enzim (E-10) lebih baik dibanding tanpa enzim (E-Oo). Rataan bobot karkas mutlak (g/ekor) dan karkas relative (\%) dapat dilihat pada Tabel 4.

Tabel 4. Rataan Bobot Karkas Mutlak (g/ekor) dan Karkas Relatif (\%)

\begin{tabular}{lccccc}
\hline \multirow{2}{*}{ Peubah } & Enzim & \multicolumn{2}{c}{ Tingkat Penggunaan } & Azolla (\%) & \multirow{2}{*}{ Rataan } \\
\cline { 3 - 5 } & $(\%)$ & A-0 & A-10 & A-20 & \\
\hline Karkas Mutlak & E-0,00 & 800,48 & 779,93 & 724,86 & $768,42^{\mathrm{b}}$ \\
(g/ekor) & $\mathrm{E}-0,10$ & 931,22 & 907,90 & 898,67 & $898,67^{\mathrm{a}}$ \\
& Rataan & $865,85^{\mathrm{a}}$ & $843,91^{\mathrm{a}}$ & $790,88^{\mathrm{b}}$ & \\
Karkas Relatif & $\mathrm{E}-0,00$ & 69,88 & 69,99 & 71,19 & 71,19 \\
(\%) & $\mathrm{E}-0,10$ & 71,68 & 74,12 & 72,34 & 72,34 \\
& Rataan & 70,78 & 72,06 & 71,77 & \\
\hline
\end{tabular}

Keterangan: Huruf kecil yang berbeda pada baris dan kolom yang sama menunjuk kan pengaruh berbeda nyata $(P<0,05)$.

Hasil penelitian ini menunjukkan bahwa terjadi penurunan bobot karkas itik yang berbeda dengan semakin tinggi tingkat penggunaan Azolla dalam ransum, hingga level $10 \%$ (A-10). Fakta menunjukkan bahwa pada tingkat penggunaan Azolla dalam ransum memberi respon positif terhadap bobot karkas, atau tidak memberi efek negatif hingga $10 \%$ (A-10\%) pada bobot karkas itik. Hal ini juga berindikasi bahwa penggunaan Azolla dalam ransum dapat diperbaiki melalui penambahan enzim selulase $(\mathrm{E}-\mathrm{0}, 10)$ dalam 
ransum sehingga mampu digunakan sebagai bahan pakan dalam ransum itik local Kerinci hingga $10 \%$.

Hasil analisis ragam menunjukkan bahwa perlakuan tingkat penggunaan Azolla dalam ransum memberi pengaruh yang tidak nyata $(\mathrm{P}>0,05)$ terhadap karkas relatif, begitu juga untuk penambahan enzim selulase dalam ransum memberi pengaruh yang tidak nyata $(\mathrm{P}>0,05)$. Interaksi antara penggunaan Azolla dan enzim selulase dalam ransum memberi pengaruh yang tidak nyata $(\mathrm{P}>0,05)$ terhadap persentase karkas. Persentase karkas ini merupakan perbandingan bobot karkas dengan bobot akhir itik atau bobot potong, sehingga bila bobot potong yang besar diikuti dengan bobot karkas yang besar pula maka persentase karkas akan tinggi dan begitu juga bila bobot karkas yang kecil akan menghasilkan persentase karkas yang rendah pula. Menurut Kardaya dan Ulupi (2005) melaporkan bahwa bobot karkas dipengaruhi oleh bobot badan akhir dan perlemakan tubuh pada waktu mencapai kondisi dipasarkan, semakin rendah bobot badan akhir maka semakin rendah bobot karkas.

\section{Nilai Ekonomis: Income Over Feed and Duck Cost (IOFC)}

Hasil perhitungan dari nilai Income Over Feed and Duck Cost (IOFDC) masing-masing kombinasi perlakuan disajikan pada Tabel 5. Rataan nilai IOFDC cenderung menurun dengan semakin tinggi tingkat penggunaan Azolla dalam ransum.

Peningkatan nilai IOFDC ini berkaitan dengan jumlah pakan yang dikonsumsi dengan harga jual itik, dimana pakan yang dikonsumsi antara A-o, A-10 dan A-20 pada masing-masing penambahan enzim selulosa $(\mathrm{E}-\mathrm{0}, 10)$ memberi pengaruh yang nyata. Di sisi lain harga ransum yang mengandung Azolla relatif lebih murah dibandingkan A-o (tanpa Azolla), sehingga mengakibatkan nilai IOFDC semakin meningkat pada masing-masing penambahan enzim (E-o,10) dengan penggunaan Azolla dalam ransum.

Nilai ekonomi dari biaya pakan ditujukan untuk melihat keuntungan dari pendapatan yang diterima dalam usaha pemeliharaan itik. Pendapatan merupakan selisih antara penerimaan dan biaya produksi. Harga ransum dihitung berdasarkan harga yang berlaku saat penelitian dilakukan, sedangkan perbedaan harga ransum yang timbul ditentukan oleh persentase atau komposisi bahan penyusun ransum percobaan masing-masing perlakuan. Nilai ekonomis ransum setiap perlakuan dihitung sebagai biaya ransum per kilogram bobot badan yang dihasilkan. Angka tersebut adalah hasil perkalian konversi ransum dengan harga ransum masing-masing perlakuan setiap kilogramnya.
Tabel 5. Nilai Ekonomis : Income Over Feed and Duck Cost (IOFDC)

\begin{tabular}{lcccccc}
\hline \multicolumn{1}{c}{ Uraian } & EOA0 & EOA10 & E0A20 & E1A0 & E1A10 & E1A20 \\
\hline Harga DOD (Rp/ekor) & 8000 & 8000 & 8000 & 8000 & 8000 & 8000 \\
Harga Ransum (Rp/kg) & 7500 & 7000 & 6500 & 8000 & 7500 & 7000 \\
$\begin{array}{l}\text { Rataan Konsumsi } \\
\text { Ransum (kg/ekor) }\end{array}$ & 4 & 4,18 & 4,057 & 3,696 & 3,76 & 3,774 \\
$\begin{array}{l}\text { Biaya Konsumsi } \\
\text { Ransum (Rp) }\end{array}$ & 29670 & 29260 & 26370,5 & 29568 & 28200 & 26418 \\
$\begin{array}{l}\text { Biaya Konsumsi Ransum } \\
\text { (Rp) + DOD (Rp) }\end{array}$ & 37670 & 37260 & 34370,5 & 37568 & 36200 & 34418 \\
$\begin{array}{l}\text { Rataan Bobot Hidup } \\
\text { (kg/ekor) }\end{array}$ & 1,146 & 1,115 & 1,021 & 1,298 & 1,228 & 1,185 \\
Harga Itik per kg (Rp/kg) & 40000 & 40000 & 40000 & 40000 & 40000 & 40000 \\
$\begin{array}{l}\text { Hasil Penjualan } \\
\text { (Rp/ekor) }\end{array}$ & 45840 & 44600 & 40840 & 51920 & 49120 & 47400 \\
Nilai IOFDC (Rp/kg) & 8170 & 7340 & 6469,5 & 14352 & 12920 & 12982 \\
\hline
\end{tabular}

Nilai IOFDC dapat mengetahui efisiensi penggunaan ransum secara ekonomis, selain memperhitungkan bobot badan akhir yang dihasilkan, juga harga ransum yang dikonsumsi. Nilai IOFDC ini diperoleh dari hasil penjualan produksi dikurangi biaya ransum untuk menghasilkan produksi (termasuk biaya bibit). Menurut Rasyaf (1989), ada tiga faktor yang mempengaruhi nilai IOFDC yaitu: jumlah ransum yang dikonsumsi, pertambahan bobot badan dan harga ransum yang diberikan. Semakin tinggi nilai IOFDC maka semakin tinggi pendapatan kotor yang diperoleh.

Hasil penelitian ini menunjukkan terjadi peningkatan pendapatan kotor pada perlakuan E-10 A10 dan E-10 A20 dimana penggunaan Azolla dalam ransum dengan penambahan enzim selulase (E10) dibanding dengan tanpa enzim (E.oo), seiring bertambahnya jumlah LSFp dan berkurangnya jumlah jagung dalam ransum. Keadaan ini disebabkan semakin banyak digunakan produk Azolla menyebabkan harga ransum lebih murah. Semakin rendah harga ransum maka akan semakin meningkat pendapatan kotor (IOFDC) yang diterima, karena nilai IOFDC diperoleh dari selisih penjualan itik dengan biaya ransum dan bibit. Menurut Behrends (1990) apabila harga ransum dapat ditekan sebanyak 2 \% saja maka keuntungan dari penjualan karkas dapat meningkat mencapai $8 \%$.

\section{KESIMPULAN}

Berdasarkan hasil dan pembahasan diatas, dapat diambil kesimpulan sebagai berikut:

1. Penggunaan Azolla dalam ransum hingga 20 $\%$ tidak mengganggu penampilan produksi itik lokal Kerinci.

2. Penambahan enzim selulosa sebanyak $0,10 \%$ dalam ransum dapat meningkatkan penampilan dan nilai ekonomis itik lokal Kerinci. 


\section{DAFTAR PUSTAKA}

Amrullah, I. K. 2003. Nutrisi Ayam broiler. Lembaga Satu Gunung Budi. Bogor.

Behrends, B.R. 1990. Nutrition economics for layers. Poultry International, 29 (1) ; $16-20$.

BPS. 2011. Statistik Indonesia. Badan Pusat Statistik, Jakarta.

Chatterjee, A., P. Sharma, M.. K. Ghosh, M. Mandal and P. K. Roy. 2013. Utilisation of Azolla microphylla as feed supplement for crossred cattle. Int. J. Agr. And Food Sci. Technology. 4(3):207-2014.

Chin, F.Y. 2002. Utilization of palm kernel cake as feed in Malaysia. Asian Livestock 26 (4):19-26.

Djojosuwito, S. 2000. Azolla Pertanian Organik dan Multiguna. Penerbit Kanisius, Yogyakarta

Hatta, U. 2005. Performan hati dan ginjal ayam broiler yang diberi ransum menggunakan ubi kayu fermentasi dengan penambahan lysine. J. Agroland.

Kardaya, D., dan N. Ulupi. 2005. Pengaruh kepadatan kandang terhadap persentase karkas dan komponen non karkas ayam pedaging. Jurnal Peternakan, Vol. 2 No. 5 September : $31-36$.

Kensch, O. 2008. Mananase engineering for fibre degradation. Speciality Chemicals Magazine. hlm 18-19.

Meng, X., B. A. Slominski, C. M. Nyachoti, L. D. Campbell, W. Guenter. 2005. Degradation of cell wall polysaccharides by combinations of carbohydrase enzymes and their effect on nutrient utilization and broiler chicken performance. Poult Sci.84:37- 47.

Musnandar, E. 2004. Pertumbuhan jamur Marasmius $s p$. pada substrat kelapa sawit untuk bahan pakan ternak. Majalah Ilmiah Angsana Vol. 08. No.3, Desember ; 25 - 30.

Noferdiman dan Zubaidah. 2012. Penggunaan Azolla microphylla fermentasi dalam ransum ayam broiler. Prosiding Seminar Nasional dan Rapat Tahunan Bidang Ilmu-Ilmu Pertanian BKS- PTN Wilayah Barat Tahun 2012, Fakultas Pertanian Universitas Sumatera Utara, Medan. Hal : 792 -799 .
Noferdiman. 1999. Penggunaan Azolla dalam ransum itik Mojosari jantan. Jurnal Ilmiah Ilmu-Ilmu Peternakan, Vol. I No.1 Edisi Mei 1999. Hal: $14-23$.

Quebral, F.C. 1988. The national Azolla action program (NAAP), Phil.Agric. 69.; p: 449 - 451.

Querubin, L. J., P. F. Alcantara, and A.O. Princesa. 1986. Chemical composition of three Azolla species (A. caroliniana, A. microphylla, and A. pinnata) and feeding value of Azolla meal in broiler ration. Phill.Agric., p: 479 - 490 .

Steel, R. G. dan H. J. Torrie. 1984. Prinsip dan Prosedur Statistik. Suatu pendekatan biometrik. Alih bahasa : B. Sumantri. PT. Gramedia Pustaka Utama, Jakarta.

Sudrajat, S. D. 2000. Potensi dan prospek bahan pakan lokal dalam mengembangkan industri peternakan di Indonesia. Seminar Nasional pada Dies Natalis UGM, Yogyakarta.

Sundu, B., Kumar, A. Dingle, J. 2005. Compariron of feeding values of palm kernel meal and copra meal for broiler. Recent advances in animal nutrition Australia.15:16a.

Supartoto, P. Widyasunu, Rusdiyanto dan M. Santoso. 2012. Ekplorasi potensi Azolla microphylla dan Lemma polirhizza sebagai produsen biomas bahan pupuk hijau, pakan itik dan ikan. Hal. 217-125 dalam: Prosiding Seminar Nasional. Purwokerto.

Wahju, J. 2004. Ilmu Nutrisi Unggas. Edisi Ke-4. Gajah Mada University Press. Yogyakarta.

Wikipedia Indonesia. 2008. Enzim. http://id.wikipedia. org/wiki/enzim. Diakses tanggal 4 Maret 2011.

Wizna. 2006. Potensi bakteri Bacillus sp. serasah hutan dalam peningkatan kualitas pakan dan implikasinya terhadap produktivitas ternak unggas. Disertasi. Program Pascasarjana Universitas Andalas, Padang.

Wood, D. A., S. E. Matcham and T. R. Fermor. 1988. Production and function on enzymes during lignocellulose degradation. In : Zadrazil, F. and P. Reninger (Eds). Treatment of lignocellulosics white rot fungi. London : Elsevier Applied Science., pp : $43-49$. 